\title{
Oil Crops Market in Serbia
}

\author{
Rade Popović · Marija Jeremić · Bojan Matkovski
}

University of Novi Sad, Faculty of Economics Subotica, Segedinski put 9-11, 24000 Subotica, Serbia

\begin{abstract}
Summary: The main objective of this paper is to identify market performances of oil crops in Serbia. In that context, development in the production and trade of main oil crops were analyzed. Sunflower, soybean and rapeseed are oil crops that are seeded on the largest areas in comparison with other oil crops, and have the biggest contribution in the value of agricultural production. This analysis used descriptive and comparative methods. Bearing in mind the increase of the world prices of oil crops, which is the result of a stronger increase of demand, as well as the importance of the oil crops in Serbia, there are more possibilities for Serbian farmers to enlarge land areas of oil crops in the structure of the agricultural production. Preferential trade agreements with the countries of European Union (EU), CEFTA, and other countries give Serbia the possibilities for strengthening of trade flows and also for additional utilization of processing capacities which this country has.

Key words: market prices, oil crops, rapeseed, Serbia, soybean, sunflower, trade
\end{abstract}

\section{Introduction}

From the perspective of the sown areas, the oil crops are the second most important crops in the world, preceded by cereals. In the last 25 years, the cultivation of oil crops gained more importance (Vollmann \& Rajcan, 2009). The future market prospects will be characterised by increasing demand for oil crops and oil crops preparations (FAO, 2015). According to the Census of Agriculture (Statistical Office of the Republic of Serbia, 2013) the three most important oil crops in Serbia are sunflower, soybean and rapeseed. They dominate the structure of arable areas of industrial crops with $97.5 \%$. The contribution of industrial crops in the total value of crop production in Serbia in the same year amounted to $14.4 \%$ (Statistical Office of the Republic of Serbia, 2014). According to statistics of the Ministry of Agriculture and Environmental Protection (2014), Serbia is one of the largest producers of oil crops and also the country with the biggest processing capacities in the region (CEFTA countries). The processing industry has the annual capacity of processing 885,600 tons of sunflower, 482,000 tons of soybean, and 247,000 tons of rapeseed. However, in the last decade, the average

Corresponding author:

knezevicm@ef.uns.ac.rs

Acknowledgement:

This study is a part of project no. TR31025 funded by Ministry of Education, Science and Technological Development of the Republic of Serbia. annual utilization of capacities for sunflower processing was $40 \%$ and for soybean processing $70 \%$. The quality of raw materials and perspective market, especially for organic soybean, offers possibilities for additional utilization of capacities (Ministry of Agriculture and Environmental Protection, 2014). In that context, the main goal of this study was to analyse the performances of oil crops market.

\section{Data Sources and Method of Research}

Performances of oil crops market were analyzed using descriptive and comparative statistical methods. Statistical data used in the analysis were collected from several sources: Statistical Office of the Republic of Serbia, Ministry of Agriculture and Environmental Protection, and Food and Agriculture Organization. According to Standard International Trade Classification (SITC) - Revision 4, the concept of oil crops and oil crops preparations covers the following basic headings: in division 08: Oil-cake and other solid residues (except dregs), whether or not ground or in the form of pellets, resulting from the extraction of fats or oils from oil crops, oleaginous fruits and germs of cereals of: soybeans, sunflower and rape or colza seeds; in division 22: Oil crops and oleaginous fruits of a kind used for the extraction of "soft" fixed vegetable oils (excluding flours and meals) of: soybean, sunflower and of rape of colza seeds, whether or not broken; in division 42: Soybean oil and its fractions (Crude oil, whether or not degummed; Refined oil and its 
fractions), Sunflower or safflower oil and fractions thereof (Crude oil; Refined oil and fractions thereof), Rape, colza or mustard oil and fractions thereof (Crude oil; Refined oil and fractions thereof). The paper is structured in three parts. Firstly, the analysis of development and prospects of oil crops world market for three major oil crops: soybean, rapeseed and sunflower is shown in order to better understand oil crops market in Serbia. In the second part, the production, yield, areas and average prices for sunflower, soybean and rapeseed are shown, while in the third part foreign trade in oil crops and oil crops preparations are given.

\section{Results and Discussion}

The world production of most important oil crops (soybean, rapeseed, and sunflower) is increasing steadily. Annually growth rate of those oil crops productions was $3.5 \%$ for the period 2004-2013. The main source of annual production growth comes from harvested area increase and in smaller amount from yield improvement, $2.4 \%$ and $1.1 \%$ respectively (FAOSTAT). Increase of production was fuelled by demand growth. Factors causing the increase of global demand for oil crops are: population growth, production of bio-fuels, and also an increased usage of the vegetable fats in comparison with the usage of the animal fats (Knezević \& Popović, 2011).

Variability of agricultural product prices is the second largest source of risk for whole agribusiness sector, but especially for farmers, since they have fewer possibilities to manage risks. In the previous decade oil crops and other agricultural products experienced turbulent price fluctuation (Figure 1). At the world market, coarse grains had the highest price volatility, followed by oil crops and wheat. Calculated coefficients of variation were: $26.4 \%, 23.4 \%$ and $17.4 \%$ respectively.
Expected enterprises profitability is the main criterion for crop selection in farm production plan. Because of that, the first level of competition for oil crops production, from farmer's point of view, comes from other enterprises and its profitability. Price signals from world market play significant role in shaping farmer's decision when it has to be chosen crops combination. So, stronger price signals may favour some crops among others. According to harvested area, maize and wheat are more important in Serbia than all oil crops together. Strong price signals shown in Figure 1 for oil crops in the period 2011-2014 were overbore by prices of wheat and coarse grains. In structure of coarse grains, maize is the main crop, participating with $80 \%$ in total production.

The production prospects for next period will be influenced by increasing demand. Population increase and economic growth are identified as the main drivers in some of the main oil consuming regions, particularly Asia (FAO, 2015). Low vegetable oil prices will also stimulate consumption. Bio diesel production slows down, and for first time decreased in 2015, because of low prices of crude oil. It caused less demand for oil crops that will continue as long as crude oil prices are at a low level.

\section{The Production of Oil Crops}

The oil crops are the second most important crops in Serbia after cereals. From the perspective of the harvested areas, the three most important oil crops are sunflower, soybean, and rapeseed. In the analysed period, the participation of those three oil crops in the total arable area increased by $0.6 \%$ per year. According to Census of Agriculture (Statistical Office of the Republic of Serbia, 2013), $14.88 \%$ of the total arable area in Serbia was sown with these three oil crops. Individually, that is $7.41 \%$ for sunflower, $7.23 \%$ for soybean, and $0.24 \%$ for rapeseed.

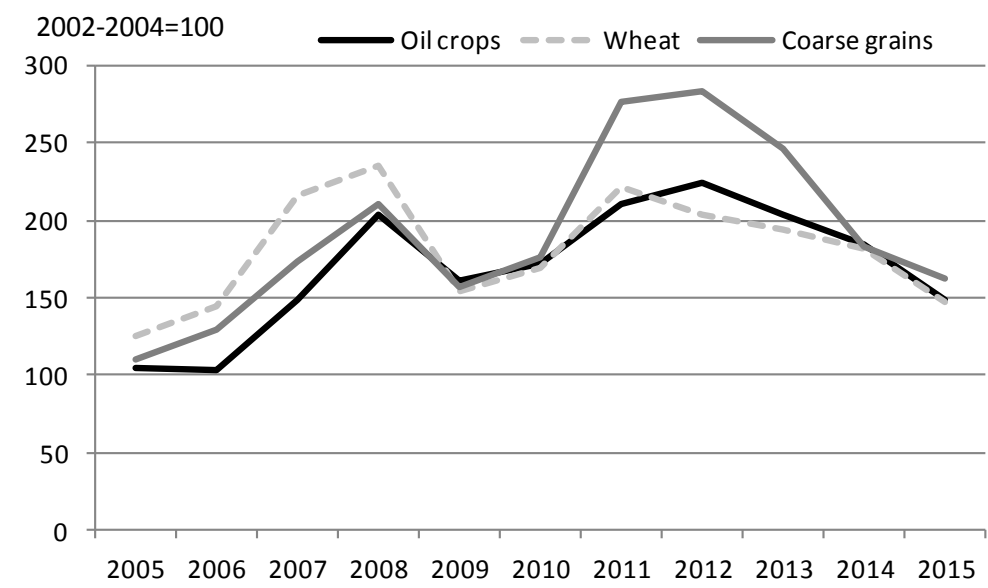

Figure 1. FAO price indexes for: oil crops, wheat and coarse grains (Source: Food Outlook) 


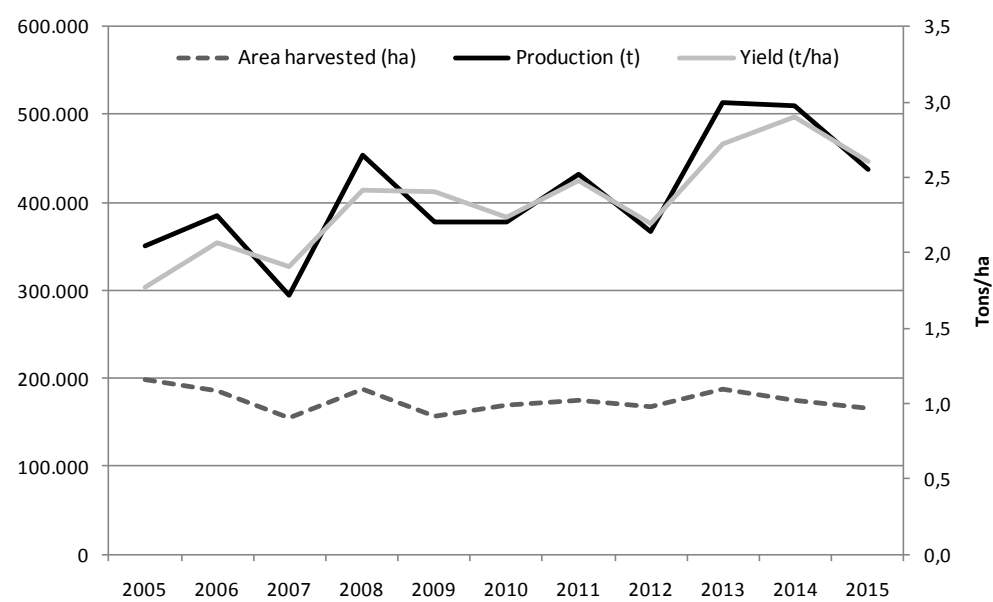

Figure 2. Dynamics of: production, yield and harvested area of sunflower in Serbia in period 2005-2015 (Source: Statistical Office of the Republic of Serbia, 2016)

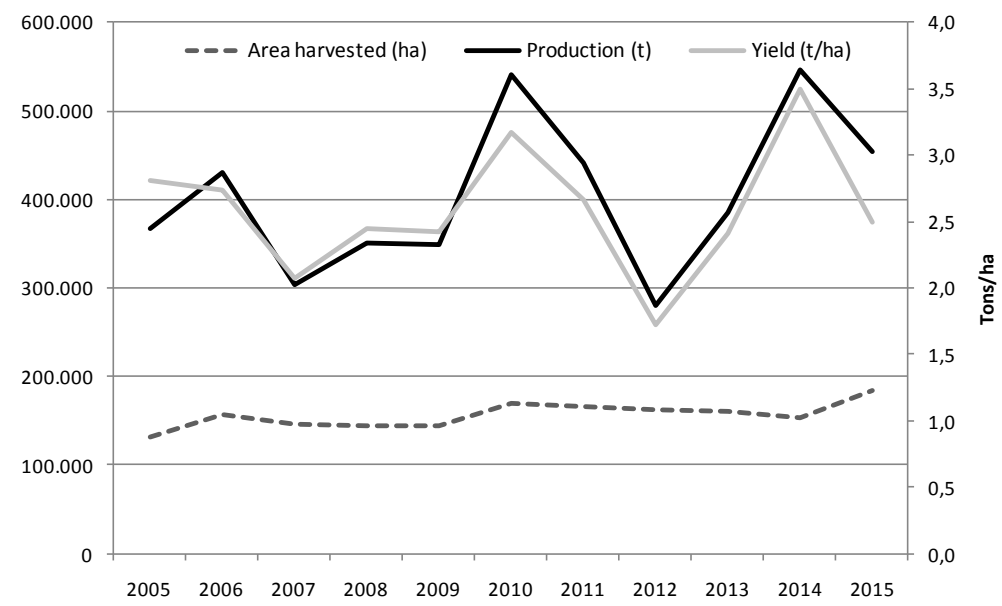

Figure 3. Dynamics of production, yield and harvested area of soybean in Serbia in period 2005-2015 (Source: Statistical Office of the Republic of Serbia, 2016)

The average growth rate of the sunflower production was $3.89 \%$ in the analysed period (Figure 2). Because of the favourable production conditions, $93.87 \%$ of the total production of sunflower is produced in the north part of Serbia (Vojvodina). According to Census of Agriculture, sunflower was produced on 28,307 farms, of which 28,046 are family farms and 261 are legal entities. Farms which produce sunflower are predominantly located in Vojvodina $(23,893)$. The majority of sunflower producers are farms with size of 5-10 ha. The largest area (35.54\% covered with sunflower) is cultivated by 980 agricultural holdings which constitute only $3.46 \%$ of the total number of agricultural holdings producing sunflower. The highest yields of sunflower were $2.9 \mathrm{t} \mathrm{ha}^{-1}$ in 2014. Annual production growth $(3.31 \%)$ was the result of yield increase $(3.88 \%)$ and negative contribution of the harvested area $(-0.60 \%)$.
In the last few years the areas covered with soybean increased from 131 to 185 thousand hectares (Figure 3), and the production of soybean increased by $2.31 \%$. Favourable climate conditions favourably affected the soybean production in 2014, when yield achieved record of $3.5 \mathrm{t} \mathrm{ha}^{-1}$. All this resulted in the largest volume of soybean production in Serbia (546,000 tons), which exceeded previous record in 2010. The growth of areas under soybean at an average annual rate of $2.11 \%$ contributed more to the production growth of soybean than the growth of yield $0.23 \%$. From 2005 to 2015, the majority share of soybean production (95.95\%) was concentrated in Vojvodina. According to Census of Agriculture, the soybean was produced on 35,246 farms, of which 34,934 were family farms and 312 are legal entities. The largest area covered with soybean (52\%) is cultivated by the farms with size 50 and more ha. 


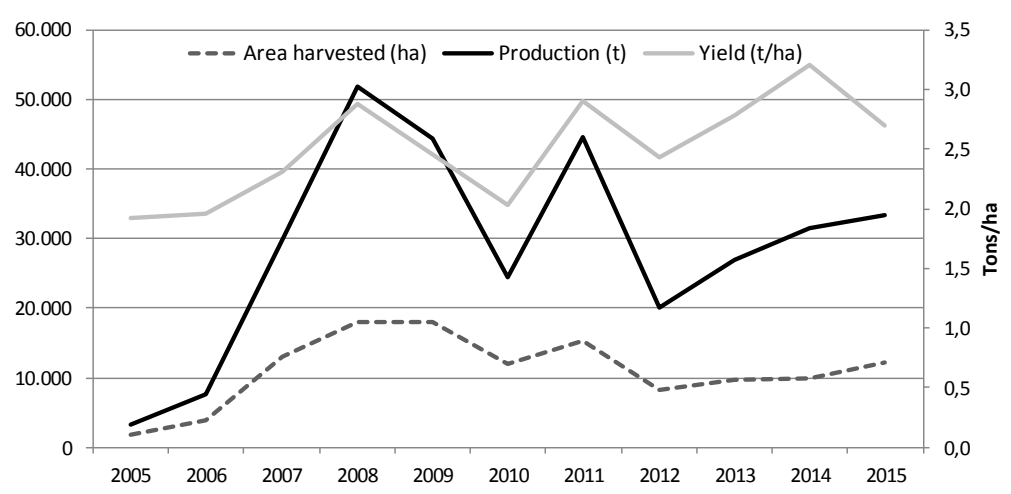

Figure 4. Dynamics of production, yield and harvested area of rapeseed in Serbia in period 2005-2015 (Source: Statistical Office of the Republic of Serbia, 2016)

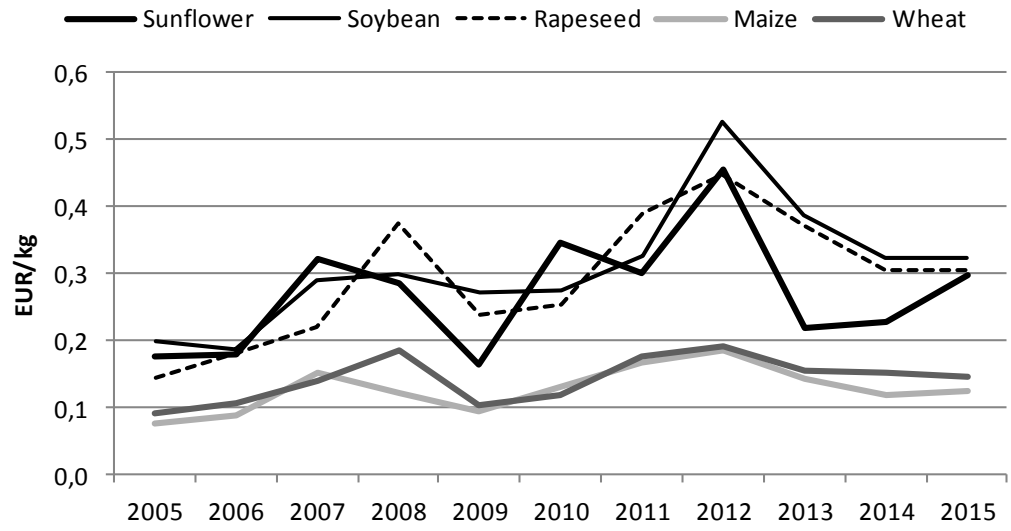

Figure 5. Average prices for main oil crops and grains in Serbia from 2005 to 2015 (in EUR) (Source: Statistical Office of the Republic of Serbia, 2016, Oanda)

In Serbia, rapeseed production has been marginally grown, covering not more than $0.7 \%$ of total arable land during previous decades. In 2007, the growth of rapeseed production was caused by opening a biodiesel plant in Šid (Popović et al., 2008). The rapeseed is produced only by 319 farms (Census of Agriculture, 2012). The highest yield of $3.2 \mathrm{t} \mathrm{ha}^{-1}$ was reached in 2014 (Figure 4).

In recent decades agricultural policy measures in Serbia supported the production of oil crops in different ways (premium per kilogram, subsidies for crop production). At the moment, there is no special support assigned solely for oil crops production. In the last few years, oil crops producers in Serbia are able to use direct payments for crop production, as well as input subsidies. Since 2013 the amount of total payments has been 12,000 RSD per hectare for farms up to 100 hectares. In 2015, only farms up to 20 hectares become eligible to get direct payments.

Crop price development, presented in Figure 5, reflects influence of the world market prices on Serbian market. Price volatility since 2007 , similarly as on world market, brings a whole range of challenges for Serbian farmers. Variability of prices was higher in case of oil crops than in case of grains. Measured by coefficient of variation, it was $43 \%$ for oil crops, $33.5 \%$ for wheat and $36.1 \%$ for maize. Comparing with world market, oil crops prices in Serbia were more volatile. As consequence of higher variability of oil crops prices the majority of farmers abstain from increase of areas under oil crops.

\section{Foreign Trade of Oil Crops}

Serbia has signed several free trade agreements which helped Serbia to increase international trade of agricultural products, including oil crops. One of the most important ones was the Stabilization and Association Agreement with EU, whose application has led to total liberalization of foreign trade with EU members states until 2014. Gradual implementation of this agreement has led to a significant reduction of duties, and in case of oil crops products, duties were completely abolished. 
The free trade of sunflower, soybean and rapeseed is also possible with other countries (besides EU member states) with which Serbia signed trade agreement. In 2006 the agreement was concluded with CEFTA member states (Bosnia and Herzegovina, FYR of Macedonia, Montenegro, Albania, Moldova, UNMIK and Croatia - until the entrance in the EU). In this agreement it was defined that there are no duties for oil crops trade.

Serbia has positive value of net trade in oil crops with world and it is increasing over time (Figure 6). Rate of export increase is stronger than import increase over analysed period. Main products on export side are sunflower, soybean and its products. On import side it is similar situation, soybean, sunflower and its products dominate. Smaller negative effects in foreign trade value are evidenced only in few years and just in case of soybean. It was caused by unfavourable production conditions.

Quantities of oil crops international trade data, presented in Figure 7, give more insight in trade patterns. Negative net trade calculated in tonnes of oil crops are recorded in several years for soybean and for sunflower only in 2006. Negative net trade volumes have wider ranges than net trade calculated in values (Figure 6). It infers that Serbia export soybean and its product with higher prices and import cheaper soybean products. In case of sunflower, Serbia had trade advantage exporting significant quantity of sunflower hybrids seed in previous period.

Key markets with which Serbia trades oil crops are CEFTA countries and some member states of the EU. According to Statistical Office of the Republic of Serbia database, the largest share of export of sunflower and sunflower preparations was placed on the: Austria, Bosnia and Herzegovina, and Croatia markets. In the structure of export value of sunflower and sunflower preparations, the most important preparation was sunflower oil (60.28\% in 2011). The most significant markets for export of soybean and soybean preparations were Italy, Bulgaria and Slovenia, whereas in the structure of export the most important preparations were soybean oil $(66.89 \%$ in 2011$)$.

In terms of import, the most important markets from which oil crops are imported are CEFTA countries, some EU member state and Brazil. Markets from which sunflower and sunflower preparations were mostly imported are Croatia and Romania. Sunflower mercantile seed is dominant in the structure of the total import of sunflower and sunflower preparations $(69.18 \%$ in 2011). The largest share of soybean and soybean preparations were imported from Bosnia and Herzegovina and Croatia. In the structure of the import of soybean and soybean preparations the most important preparation was oil cake (58.55\% in 2011).

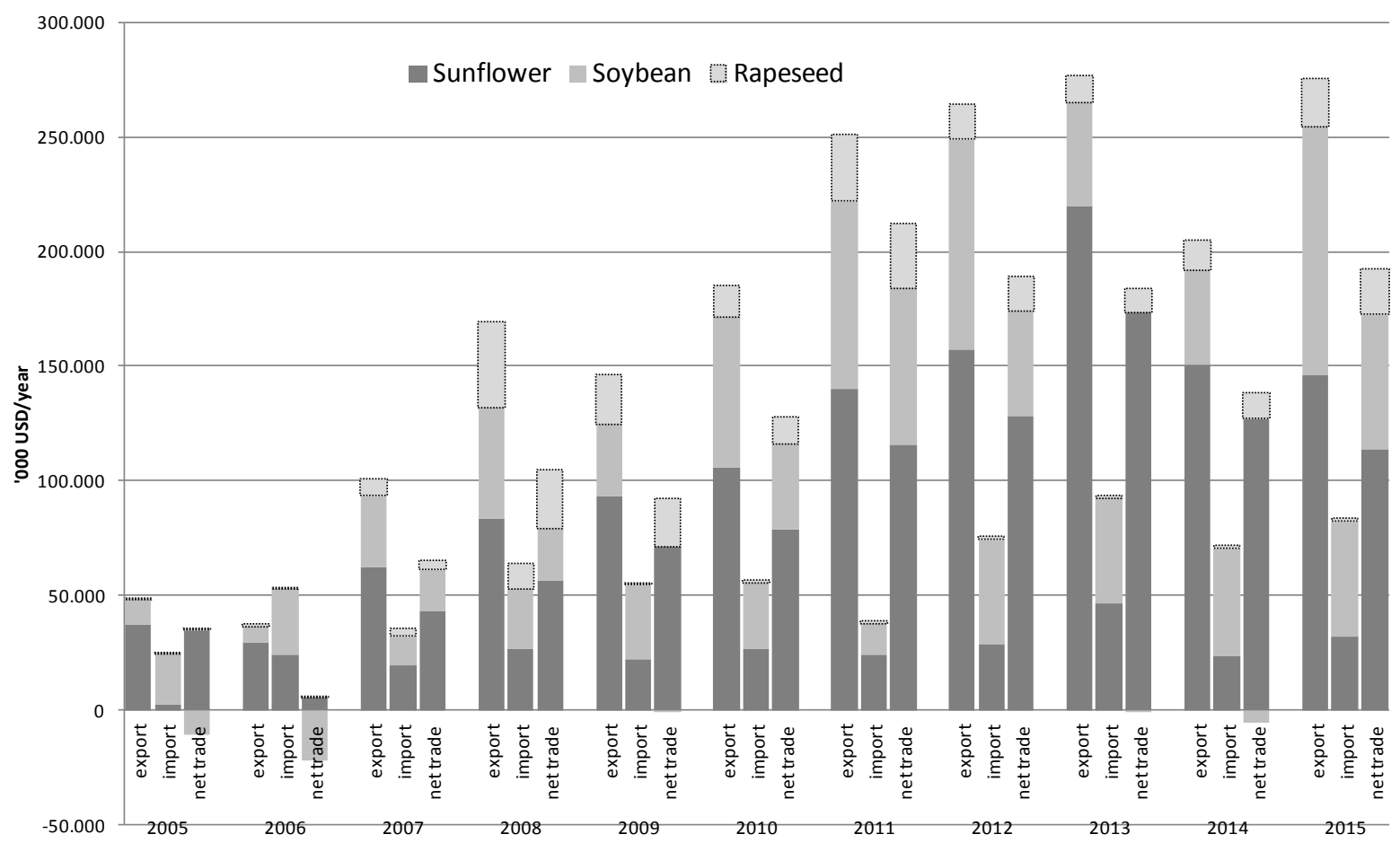

Figure 6. Serbian foreign trade in oil crops from 2005 to 2015 (in USD) (Source: Statistical Office of the Republic of Serbia, 2016) 


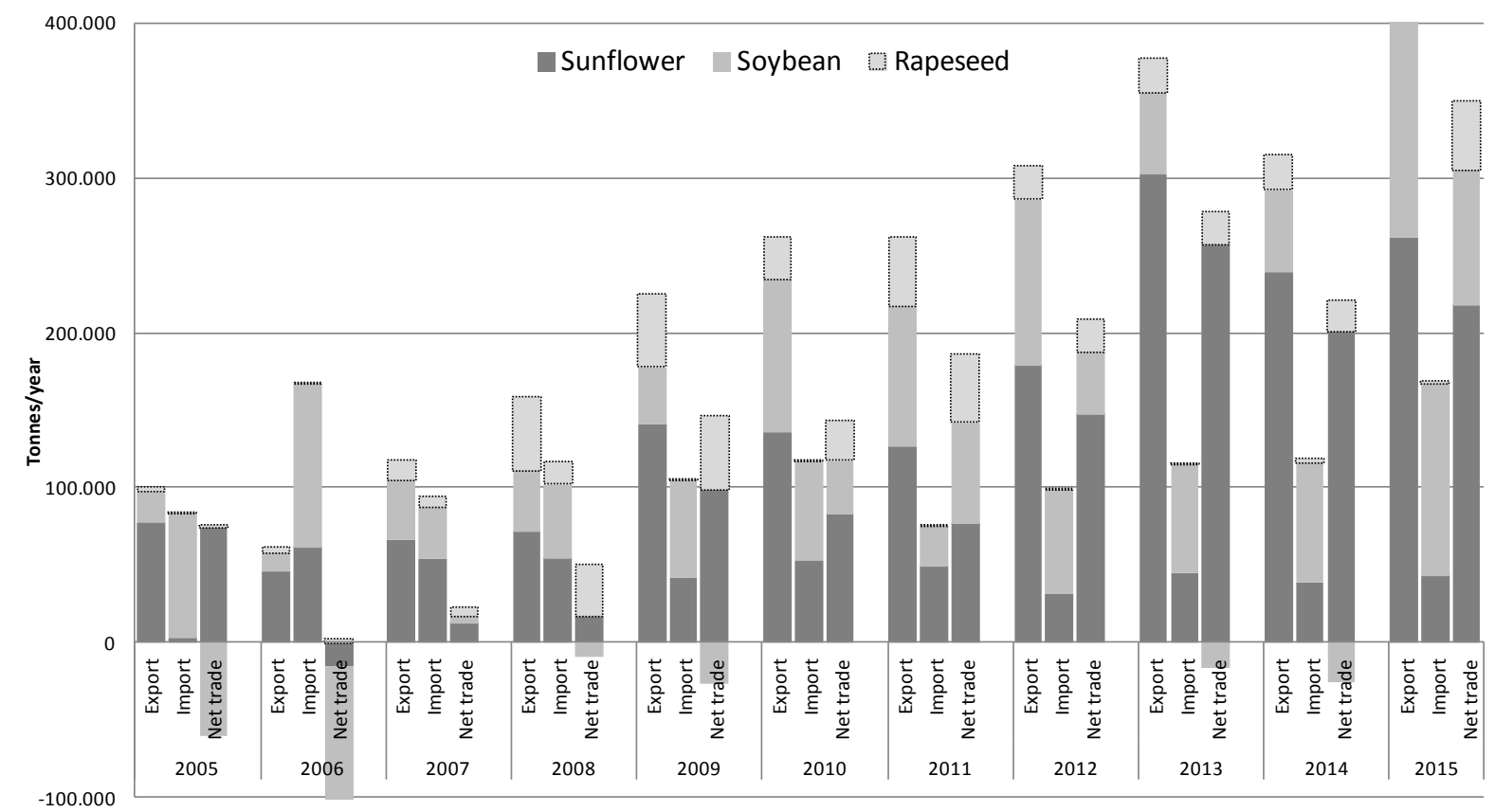

Figure 7. Serbian foreign trade in oil crops from 2005 to 2015 (in t) (Source: Statistical Office of the Republic of Serbia, 2016)

\section{Conclusion}

The world production of main oil crops increases steadily. This growth was caused by population growth, increased use of oil crops in bio-fuel production and increased use of vegetable oils in human nutrition. In Serbia, oil crops are the second most important crops after cereals. In terms of harvested area, three most important oil crops in Serbia are sunflower, soybean and rapeseed. The share of sunflower and soybean in structure of total arable area is close to $15 \%$, while rapeseed has marginal position $(0.24 \%)$. Because of the favourable production conditions, the largest part of oil crops production is situated in the north part of Serbia.

By signing free trade agreements with EU, CEFTA and other countries, tariff barriers were abolished on imports of oil crops for the main foreign trade partners. Accordingly to this, Serbia has positive value of net trade in oil crops with world and it is increasing over time. Main products on export side, as on import side, are sunflower, soybean and its preparations. The key international markets of oil crops are region countries and some member states of the EU. In the structure of the oil crops export, the most important preparation was sunflower oil, while in the structure of import, a dominant preparation was soybean cake. The trade with rapeseed preparations does not have greater financial importance for Serbia.

\section{References}

FAO (2015). FAO Food Outlook October 2015. Rome, Italy. Retrieved on 15 March 2016 from http://www.fao.org/fileadmin/ user_upload/newsroom/docs/Food $\% 20$ Outlook $\% 20$ October $\%$ 202015.pdf

FAO (2016). Data base. Rome, Italy. Retrieved on 15 March 2016 from http:// faostat.fao.org/site/291/default.aspx

FAO (2016). World food situation. Retrieved on 15 March 2016 from http://www.fao.org/worldfoodsituation/en/

Knežević, M., \& Popović, R. (2011). Ekonomski aspekti proizvodnje suncokreta u Srbiji. Ratarstvo i povrtarstvo, 48(1), 213-218.

Ministry of Agriculture and Environmental Protection (2014). Strategy of Agriculture and rural development of the Republic of Serbia. Belgrade, MAEP. Retrieved from: http://uap.gov.rs/wp-content/themes/ uap/STRATEGIJA \%202014-2020\%20.pdf

OANDA (2016). Historical exchange rates. Retrieved on 15 March 2016 from http://www.oanda.com/

Popović, R., Stojšin, V., \& Knežević, M. (2008). Tržište i ekonomski aspekti proizvodnje uljane repice u Srbiji. Anali Ekonomskog fakulteta u Subotici, 20, 75-83.

Statistical Office of the Republic of Serbia (2013). Census of Agriculture. Agriculture in the Republic of Serbia (I). Belgrade, Serbia: Statistical Office of the Republic of Serbia.

Statistical Office of the Republic of Serbia (2014). Economic Accounts for Agriculture in the Republic of Serbia 2007-2014. Retrieved from http://pod2.stat.gov.rs/ObjavljenePublikacije/G2014/pdf/ G20149081.pdf

Statistical Office of the Republic of Serbia (2016). Data base. Retrieved from http://webrzs.stat.gov.rs/WebSite/public/ReportView.aspx

Statistical Office of the Republic of Serbia (2016). Monthly statistical builten 12/2015. Retrieved from http://pod2.stat.gov.rs/ ObjavljenePublikacije/G2016/pdf/G20163003.pdf

Vollman, J.,\& Rajcan, I. (2009). Oil Crops: Handbook of Plant Breeding. New York: Springer. 


\section{Tržište uljarica u Srbiji}

\section{Rade Popović · Marija Jeremić · Bojan Matkovski}

Sažetak: Cilj rada je identifikovanje tržišnih performansi uljarica u Srbiji. U tom smislu, analiziraju se tendencije u proizvodnji i trgovini najznačajnijih uljanih kultura u Srbiji. Sa aspekta zasejanih površina tri najznačajnije uljane kulture u Srbiji su suncokret, soja i uljana repica. Takođe, ove kulture imaju i najveći udeo u ostvarenoj vrednosti poljoprivredne proizvodnje u odnosu na ostale uljarice. U radu su korišćeni deskriptivni i komparativni metod. Imajući u vidu rast svetskih cena uljarica prouzrokovan rastom tražnje za istim, kao i značaj uljanih kultura u Srbiji otvaraju se mogućnosti poljoprivrednim proizvođačima Srbije da u većem obimu uključe uljarice u strukturu ratarske proizvodnje. Preferencijalni trgovinski sporazumi sa zemljama Evropske unije (EU), CEFTE i drugim zemljama otvaraju dodatne mogućnosti za jačanje trgovinskih veza i dodatno iskorišćenje prerađivačkih kapaciteta kojima Srbija raspolaže.

Ključne reči: soja, Srbija, suncokret, trgovina, tržišne cene, uljana repica, uljarice 